\title{
Stem Tissue Dimensions Correlate with Vulnerability to Injury for Six Cycas Species
}

\author{
Thomas E. Marler ${ }^{1}$ \\ College of Natural and Applied Sciences, UOG Station, University of Guam, \\ Mangilao, Guam 96923
}

\section{Anders Lindström \\ Nong Nooch Tropical Botanic Garden and Resort, Chonburi 20260, Thailand}

Jack B. Fisher

Fairchild Tropical Botanic Garden, 11935 Old Cutler Road, Coral Gables, FL 33156

Additional index words. cycads, Cycas edentata, Cycas elongata, Cycas hainanensis, Cycas macrocarpa, Cycas pectinata, Cycas revoluta

\begin{abstract}
Dimensions of pith, vascular tissue, cortex, live leaf bases, and periderm layers comprising the diameter of the stems of six Cycas species were measured at the standardized stem height where two vascular cylinders existed. The six species represent a range in susceptibility to injuries that occur in routine horticultural operations. We assigned a subjective numeric ranking from 1 for difficult to 10 for easy and then determined if this ranking correlated with any of the dimension characteristics. Pith diameter and cortex width differed among the species with the highly sensitive $C$. macrocarpa Griff. exhibiting the widest pith and most narrow cortex. Width of tissues peripheral to the vascular tissue (cortex, leaf base, and periderm layers) also differed among the species as did the proportion of total stem diameter occupied by these peripheral tissues. The sensitive $C$. macrocarpa exhibited the smallest values for these two variables. Simple correlation and multiple regression analyses indicated cortex width, total stem diameter, absolute width of peripheral tissues, and the relative proportion of these peripheral tissues in relation to stem diameter were positively correlated with susceptibility ranking. Of these, the relative proportion of peripheral tissues emerged as the variable with the most significant association with susceptibility ranking. Among these six representative species, the species that tend to be least susceptible to injuries during horticultural operations protect the youngest vascular tissues within a relatively wide zone of peripheral tissue. In contrast, the sensitive species exhibit a narrow zone of protective peripheral tissues.
\end{abstract}

Several cycad species have entered the horticulture industry with Cycas revoluta Thunb. (Fig. 1A) represented more than any other taxa. All species of this group of dioecious gymnosperms are of value to collectors because of their ancient position in spermatophyte evolution and their unique morphological features (Norstog and Nicholls, 1997). The columnar stem of arborescent cycad species (Fig. 2A) lacks thin twigs and is therefore classified as pachycaulous (Stevenson, 1980). Cycad stems have concentric cylinders of vascular tissue that contain soft, parenchymatous xylem tissue and

\footnotetext{
Received for publication 8 Mar. 2010. Accepted for publication 12 May 2010.

Financial support was provided by J.J. Mauget Company and the Western Pacific Tropical Research Center, University of Guam.

We thank Mr. Kampon Tanshacha for availability of plant material and William Tang for Figure 1A. ${ }^{1}$ To whom reprint requests should be addressed; e-mail tmarler@uguam.uog.edu.
}

little lignified tissue with each new additional cylinder differentiating at the base of the stem between the cortex and the youngest preexisting cylinder (Bork, 1990; Chamberlain, 1935; Terrazas, 1991). Persistent parenchymatous pith and cortex are not replaced by wood or phloem like in more typical woody plants. Active cambial activity occurs within every vascular cylinder regardless of plant or vascular cylinder age, and parenchymatous rays connect the cortex and pith tissue (Terrazas, 1991).

Cycas male cones are striking organs that add horticultural appeal (Fig. 2B). The genus Cycas differs from other cycad genera in having loosely arranged megasporophylls rather than a true female cone. Structure of the female reproductive structure varies among Cycas species with megasporophylls opening up in some species to eventually radiate out and then down from the stem apex (Fig. 2C) or remaining upright in other species to retain a globular shape (Fig. 2D). Both male cones and female structures are conspicuous, are important for taxonomic classifications, and add interest in any horticultural application.

More than half of the described cycad taxa are threatened or endangered (Donaldson, 2003), so very few studies have been conducted that require destructive sampling techniques. Of those that have been conducted, most of the focus has been on seedlings because they are relatively less valuable (Norstog and Nicholls, 1997). We recently studied the use of highpressure stem injection of insecticides for use on six Cycas species to evaluate efficacy for control of Aulacaspis yasumatsui Takagi and resolve how the pachycaulous stem would respond to the treatment. We determined that the stem's succulent nature was highly susceptible to secondary infection whenever the protective external tissues were removed or the internal tissues were injured (Fisher et al., 2009).

We used this rare opportunity of access to large Cycas specimens to determine the size relations of various tissue categories within these stems that were necessarily sacrificed. We included $C$. revoluta, which is the most hearty Cycas species in horticulture, and $C$. edentata de Laub. and C. macrocarpa Griff., which have reputations for being highly susceptible to injuries that occur during various horticulture activities. We additionally included C. elongata (Leandri) D. Yue Wang, C. hainanensis C.J. Chen, and C. pectinata Griff. because they are intermediate in susceptibility to injury. The general appearance of large pinnately compound leaves radiating from the apex of a robust columnar stem is fairly similar among these six arborescent Cycas species (Fig. 1).

Understanding the characteristics of the cycad stem is crucial in horticulture, because this structure is transplanted and even marketed devoid of leaves and lateral roots (Fig. 2A). Our primary objective here was to determine how differences in stem structure may explain the differences in susceptibility to injury among the species. This information may explain why $C$. revoluta and other species are easy to grow and help improve management techniques for the species that are difficult to manage.

\section{Materials and Methods}

The plants were selected from the landscape production stock at Nong Nooch Botanical Garden and Resort, Chonburi, Thailand, in Apr. 2007. The total number of plants examined for the following species are given in parentheses: Cycas edentata (five), C. elongata (two), C. hainanensis (two), $C$. macrocarpa (two), C. pectinata (16), and $C$. revoluta (two). The number of available plants was variable and limited to those used in the study noted previously. Because of the value of these large specimens, we could not dissect more plants. The healthy plants were 6 to 7 years old, had well-developed stems with three or more vascular cylinders toward the base, and were cultivated in pots (height $40 \mathrm{~cm} \times$ diameter $35 \mathrm{~cm}$ ) in a shadecloth production area. They had received routine 

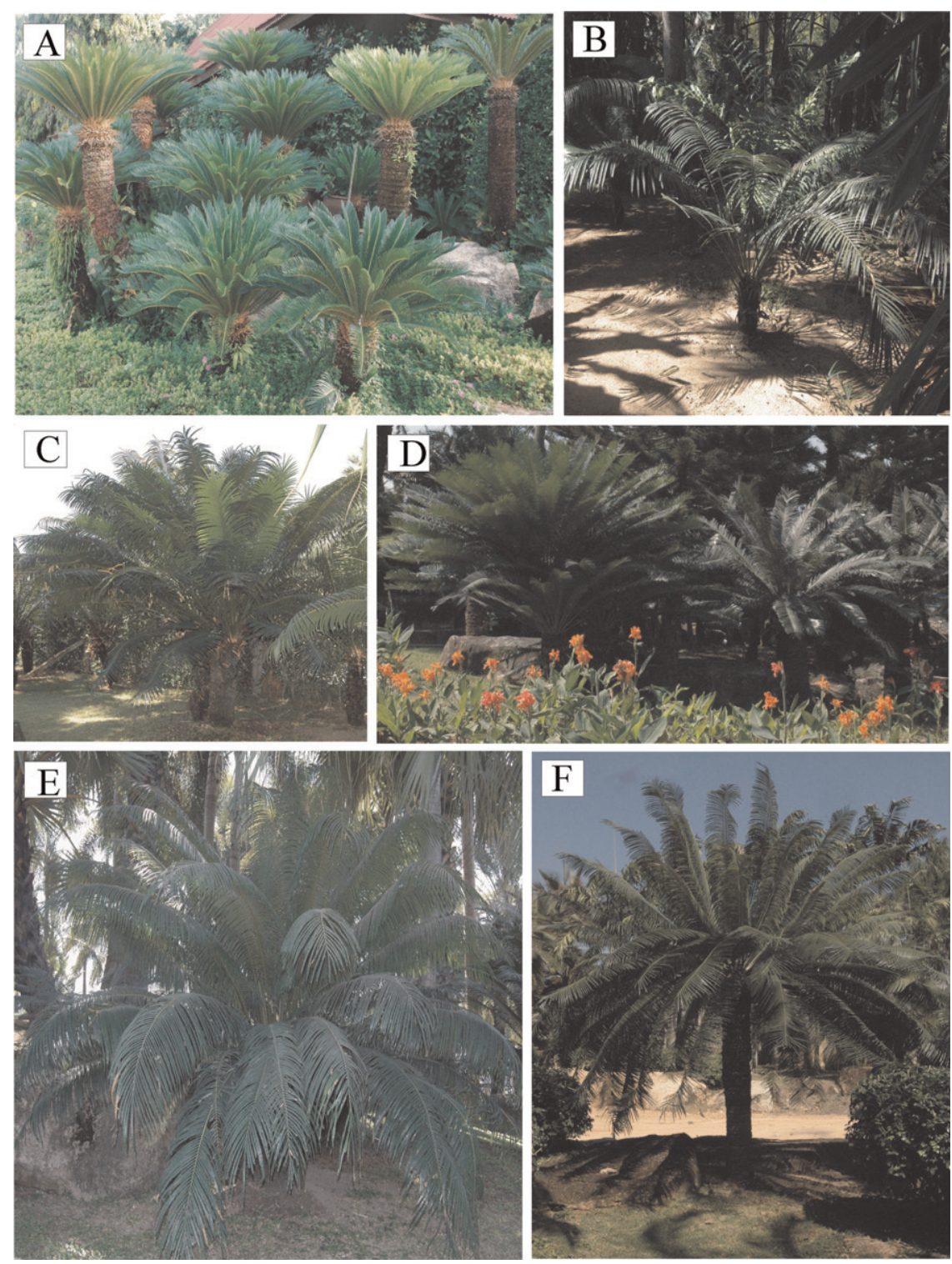

Fig. 1. Habit of large specimens of (A) Cycas revoluta; (B) C. macrocarpa; (C) C. edentata; (D) C. elongata; (E) C. hainanensis; and (F) C. pectinata.

fertilization and irrigation used in this large commercial operation.

Number of basal vascular cylinders and stem diameter varied among the replications. For comparative purposes, we used a standardized stem location in which two vascular cylinders existed and avoided the anatomically unusual basal part of the stem. This ensured we focused on developmentally equivalent stem regions. We measured diameter of pith and radial thickness of the vascular cylinders, cortex, live leaf base stubs, and periderm layers (Fig. 2E) in stems cut transversely.

We assigned a relative ranking based on our collective experiences and discussion with other cycad collectors (Table 1). This subjective ranking ranged from 1 for $C$. macrocarpa as the most difficult species to 10 for $C$. revoluta as the most stalwart species. The ranking is primarily based on susceptibility to injury during horticultural lated with our ranking. Finally, to define which of the variables had the best association with the ranking, we used a multiple regression model comprised of the five directly measured dimensions and a second multiple regression model comprised of the three derived variables.

\section{Results and Discussion}

Stem dimensions. Width of cortex differed among the species $(\mathrm{F}=18.13, P \leq 0.0001)$. The three species intermediate in susceptibility ranking exhibited wider cortex than the remaining species (Table 1). Pith diameter was also influenced by species $(\mathrm{F}=13.31$, $P \leq 0.0001)$. Pith diameter was greatest in $C$. macrocarpa and $C$. hainanensis and least in C. edentata and C. revoluta (Table 1). Total stem diameter varied among the species ( $\mathrm{F}=16.40, P \leq 0.0001)$. Cycas hainanensis exhibited the widest stems at this standardized height in which two vascular rings existed, whereas C. edentata, C. macrocarpa, and $C$. revoluta exhibited the most narrow stems (Table 1). The absolute width of peripheral tissue was the most heterogeneous variable $(\mathrm{F}=19.68, P \leq 0.0001)$ with the six species separating into four distinct groups (Table 1). Cycas macrocarpa exhibited the most narrow zone of peripheral tissue, whereas $C$. hainanensis and $C$. elongata exhibited the widest zone of peripheral tissue. Our derived variable calculated as the relative proportion of total stem diameter occupied by the peripheral tissue was influenced by species $(\mathrm{F}=15.03, P \leq 0.0001)$ with $C$. macrocarpa exhibiting the smallest value (Table 1). The width of live leaf bases $(P=0.0677)$, periderm $(P=0.7904)$, and vascular tissue $(P=0.5376)$ were not influenced by species.

Correlations with susceptibility ranking. The Pearson correlation coefficients from the Poisson regression analysis of each variable were not significant for width of live leaf bases, periderm, pith, and vascular tissue. In contrast, width of cortex, total stem diameter, width of peripheral tissue, and the relative proportion of peripheral tissue were all positively correlated with susceptibility ranking (Table 2). The relative proportion of peripheral tissue exhibited the highest level of significance from among these correlations of susceptibility ranking with individual variables.

The multiple regression model based on our three derived variables [Akaike's Information Criterion with a second order correction $($ AICC) statistic $=121.36$ ] gave a better fit than the model based on the five measured variables $($ AICC statistic $=132.24)$. The only significant source of variation within the model based on measured variables was cortex $(P=$ $0.005)$. In contrast, total stem diameter $(P=$ $0.0488)$ and the relative proportion of peripheral tissue $(P=0.0185)$ were significant contributors to the model based on derived variables.

Interpretations. The vascular tissues of Cycas stems are highly susceptible to direct 
damage by physical pressure (Fisher et al., 2009). Our results indicate a relatively wide zone of protective cortex, leaf base, and periderm tissues may explain the differences in susceptibility to injury for these six Cycas species. The individual contributions of each tissue category were less important than was the combined peripheral tissue. For example,
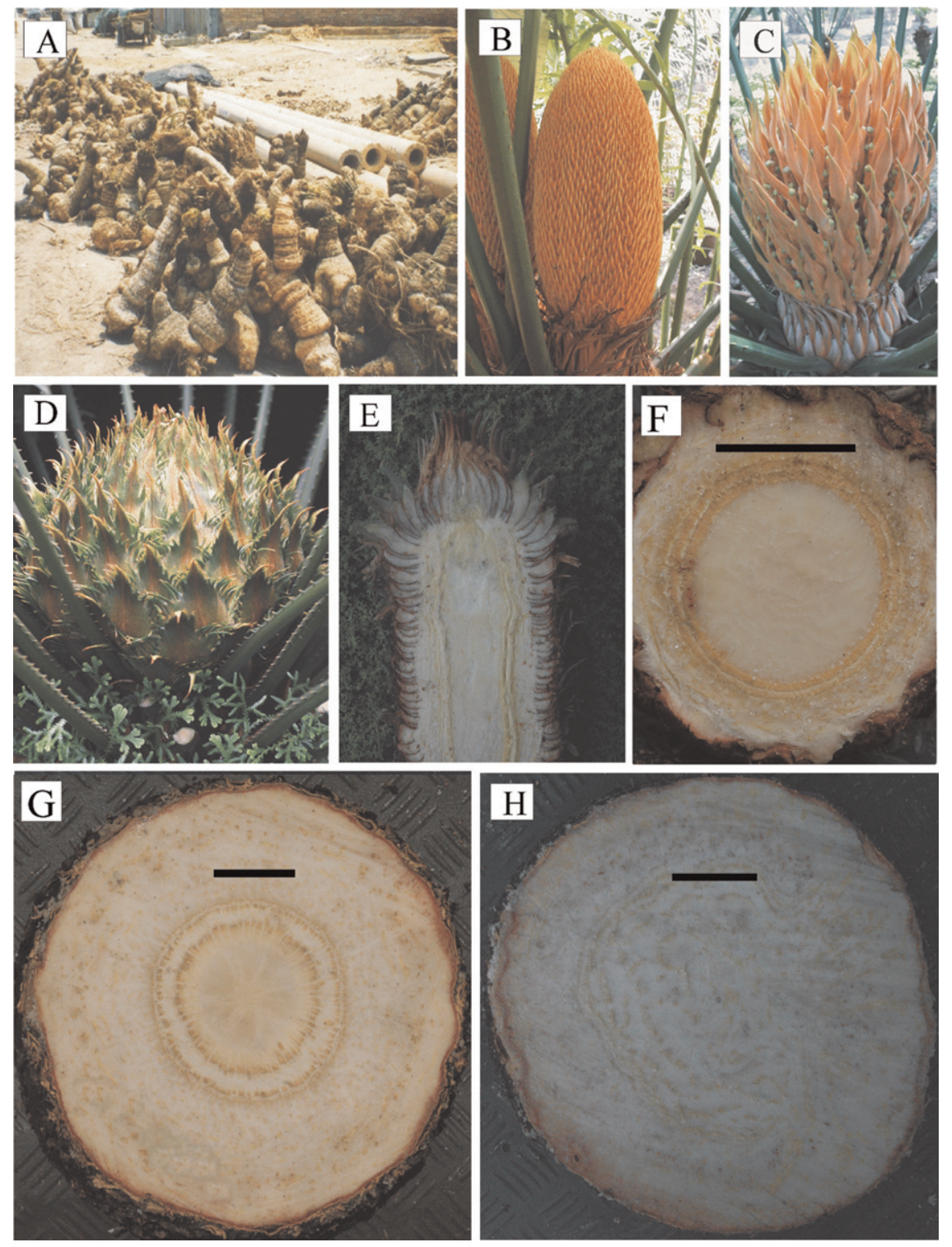

Fig. 2. Characteristics of Cycas morphology. (A) The "caudex" is the structure of this Cycas being sold in a Chinese market (photographed by William Tang); (B) C. edentata male cone morphology; (C) $C$. edentata female megasporophylls; (D) C. hainanensis megasporophylls; (E) C. revoluta cut stem showing (from periphery to center) dark periderm tissue, live leaf bases, cortex, vascular tissue (dark vertical lines), and pith;(F) C. edentata cut stem revealing relatively narrow cortex; (G) C. hainanensis cut stem revealing relatively wide cortex; $(\mathbf{H})$ base of a $C$. pectinata caudex showing scattered vascular tissue. Scale bar for $\mathbf{F}, \mathbf{G}, \mathbf{H}=5 \mathrm{~cm}$. although the least susceptible $C$. revoluta exhibited the greatest leaf base width, $C$. macrocarpa leaf base width was not different from that of the remaining four species despite its ranking as most susceptible. Second, although $C$. macrocarpa exhibited the most narrow cortex, C. revoluta cortex width was less than three other more sensitive species. Third, for total stem diameter at the standardized height of two vascular rings, both $C$. macrocarpa and $C$. revoluta were among the most narrow. Therefore, the only variable that positioned $C$. revoluta on one extreme and $C$. macrocarpa on the opposite extreme was the relative proportion of stem diameter occupied by the peripheral tissue. The correlations corroborated these ANOVA results in that the relative proportion of peripheral tissue exhibited the highest level of significance within the two multiple regression models and among the separate correlations of susceptibility ranking with individual variables.

The terms stem and caudex are used interchangeably by cycad biologists (e.g., Walters and Osborne, 2004). The term caudex has historically been used to describe the axis of a plant, which may include stem and root tissue (Jackson, 1928). The obvious stem region of the Cycas caudex contains visible leaf scars and well-defined vascular cylinders (Norstog and Nicholls, 1997). We are the first to report that the vascular cylinders disappear at the very base of a large Cycas caudex and are replaced by an irregular pattern of vascular bundles (Fig. 2H). The term caudex has little botanical value, and it is used as a convenient descriptor. Its continued use in the cycad literature as a synonym of stem should be discontinued because our results indicate the ontogenetic nature of the basal portion is ambiguous.

Table 2. Pearson correlation coefficients for the relationship between ranking for susceptibility to damage (general ranking of 1 for most susceptible to 10 for least susceptible) and four measured and derived descriptions of stem tissue dimensions $(\mathrm{N}=29)$.

\begin{tabular}{|c|c|c|}
\hline Variable & Coefficient & Significance \\
\hline Cortex & 0.53389 & 0.0029 \\
\hline Total stem diameter & 0.42068 & 0.0231 \\
\hline Peripheral tissue $^{z}$ & 0.61754 & 0.0004 \\
\hline $\begin{array}{l}\text { Relative proportion } \\
\text { of peripheral tissue }\end{array}$ & 0.74327 & $<0.0001$ \\
\hline
\end{tabular}

${ }^{\mathrm{z}}$ Cortex + live leaf bases + periderm.

Table 1. Subjective ranking for susceptibility to injury during routine horticultural operations and tissue category dimensions for stems of six Cycas species.

\begin{tabular}{|c|c|c|c|c|c|c|c|c|c|}
\hline Species & $\begin{array}{l}\text { Hort } \\
\operatorname{rank}^{2}\end{array}$ & $\begin{array}{c}\text { Pith } \\
\text { diam. (mm) }\end{array}$ & $\begin{array}{c}\text { Vascular } \\
\text { width }(\mathrm{mm})\end{array}$ & $\begin{array}{c}\text { Cortex } \\
\text { width }(\mathrm{mm})\end{array}$ & $\begin{array}{l}\text { Live leaf base } \\
\text { width }(\mathrm{mm})\end{array}$ & $\begin{array}{c}\text { Periderm } \\
\text { width }(\mathrm{mm})\end{array}$ & $\begin{array}{c}\text { Peripheral } \\
\text { tissue }(\mathrm{mm})\end{array}$ & $\begin{array}{c}\text { Total } \\
\text { diam. }(\mathrm{mm})\end{array}$ & $\begin{array}{c}\text { Proportion } \\
\text { peripheral tissue }\end{array}$ \\
\hline C. edentata & 4 & $47.7 \mathrm{c}^{\mathrm{x}}$ & $12.1 \mathrm{a}$ & $20.5 \mathrm{~b}$ & $10.9 \mathrm{ab}$ & $1.0 \mathrm{a}$ & $32.4 \mathrm{c}$ & $136.7 \mathrm{c}$ & $0.474 \mathrm{~b}$ \\
\hline C. elongata & 7 & $63.8 \mathrm{~b}$ & $11.6 \mathrm{a}$ & $51.6 \mathrm{a}$ & $7.8 \mathrm{ab}$ & $1.0 \mathrm{a}$ & $60.4 \mathrm{ab}$ & $207.8 \mathrm{~b}$ & $0.581 \mathrm{a}$ \\
\hline C. hainanensis & 7 & $79.8 \mathrm{a}$ & $18.9 \mathrm{a}$ & $61.1 \mathrm{a}$ & $10.0 \mathrm{ab}$ & $1.0 \mathrm{a}$ & $72.1 \mathrm{a}$ & $261.8 \mathrm{a}$ & $0.551 \mathrm{ab}$ \\
\hline C. macrocarpa & 1 & $79.8 \mathrm{a}$ & $17.3 \mathrm{a}$ & $13.5 \mathrm{~b}$ & $4.3 \mathrm{~b}$ & $1.0 \mathrm{a}$ & $18.8 \mathrm{~d}$ & $151.8 \mathrm{c}$ & $0.243 \mathrm{c}$ \\
\hline C. pectinata & 7 & $67.0 \mathrm{~b}$ & $17.4 \mathrm{a}$ & $49.1 \mathrm{a}$ & $6.9 \mathrm{~b}$ & $1.2 \mathrm{a}$ & $57.2 \mathrm{~b}$ & $216.0 \mathrm{~b}$ & $0.529 \mathrm{ab}$ \\
\hline C. revoluta & 10 & $41.5 \mathrm{c}$ & $11.8 \mathrm{a}$ & $22.4 \mathrm{~b}$ & $14.8 \mathrm{a}$ & $1.0 \mathrm{a}$ & $38.1 \mathrm{c}$ & $141.3 \mathrm{c}$ & $0.539 \mathrm{ab}$ \\
\hline
\end{tabular}

${ }^{\mathrm{z}} 1=$ most susceptible, $10=$ least susceptible.

yProportion of total stem diameter comprised of combined width of peripheral tissue (cortex + leaf base + periderm).

${ }^{\mathrm{x}}$ Any two means within a column not followed by the same letter are significantly different based on least significant difference. 


\section{Literature Cited}

Bork, J. 1990. Developmental cycles in shoot growth of male Cycas circinalis. Amer. J. Bot. 77:981-985.

Chamberlain, C.J. 1935. Gymnosperms: Structure and evolution. University of Chicago Press, Chicago, IL. [1966 reprint; Dover Publications, New York, NY].

DonaldsonJ.S. (ed.). 2003. Cycads: Status survey and conservation action plan. IUCN/SSC
Cycad Specialist Group. International Union for Conservation of Nature, Gland, Switzerland.

Fisher, J.B., A. Lindström, and T. Marler. 2009. Tissue responses and solution movement after stem wounding in six Cycas species. HortScience 44:848-851.

Jackson, B.D. 1928. Dictionary of botanical terms. 4th Ed. Duckworth \& Co., London, UK.
Norstog, K.J. and T.J. Nicholls. 1997. The biology of the cycads. Cornell University Press, Ithaca, NY. Stevenson, D.W. 1980. Radial growth in the Cycadales. Amer. J. Bot. 67:465-475.

Terrazas, T. 1991. Origin and activity of successive cambia in Cycas (Cycadales). Amer. J. Bot. 78: 1335-1344.

Walters, T. and R. Osborne (eds.). 2004. Cycad classification: Concepts and recommendations. CABI Publishing, Cambridge, MA. 